\title{
Zoonotic hepatitis E: animal reservoirs and emerging risks
}

\author{
Nicole PAVIo ${ }^{1 *}$, Xiang-Jin $\mathrm{MenG}^{2}$, Christophe Renou ${ }^{3}$ \\ ${ }^{1}$ UMR 1161 Virologie AFSSA LERPAZ, ENVA, INRA, École Nationale Vétérinaire d'Alfort, \\ 7 avenue du Général de Gaulle, 94704 Maisons-Alfort, France \\ ${ }^{2}$ Centre for Molecular Medicine and Infectious Diseases, Department of Biomedical Sciences and Pathobiology, \\ College of Veterinary Medicine, Virginia Polytechnic Institute and State University, Blacksburg, Virginia, USA \\ ${ }^{3}$ Hôpital de Jour, Centre Hospitalier de Hyères, rue du Maréchal-Juin, 83400 Hyères, France
}

(Received 2 November 2009; accepted 1 April 2010)

\begin{abstract}
Hepatitis E virus (HEV) is responsible for enterically-transmitted acute hepatitis in humans with two distinct epidemiological patterns. In endemic regions, large waterborne epidemics with thousands of people affected have been observed, and, in contrast, in non-endemic regions, sporadic cases have been described. Although contaminated water has been well documented as the source of infection in endemic regions, the modes of transmission in non-endemic regions are much less known. HEV is a single-strand, positive-sense RNA virus which is classified in the Hepeviridae family with at least four known main genotypes (1-4) of mammalian HEV and one avian HEV. HEV is unique among the known hepatitis viruses, in which it has an animal reservoir. In contrast to humans, swine and other mammalian animal species infected by HEV generally remain asymptomatic, whereas chickens infected by avian HEV may develop a disease known as Hepatitis-Splenomegaly syndrome. HEV genotypes 1 and 2 are found exclusively in humans while genotypes 3 and 4 are found both in humans and other mammals. Several lines of evidence indicate that, in some cases involving HEV genotypes 3 and 4, animal to human transmissions occur. Furthermore, individuals with direct contact with animals are at higher risk of HEV infection. Crossspecies infections with HEV genotypes 3 and 4 have been demonstrated experimentally. However, not all sources of human infections have been identified thus far and in many cases, the origin of HEV infection in humans remains unknown.
\end{abstract}

hepatitis E virus (HEV) / cross-species transmission / zoonosis / animal reservoir / food safety

\section{Table of contents}

1. Introduction.

2. Hepatitis E virus biology and classification............................................................................. 2

2.1. Morphology, genome organization, and protein expression .............................................. 2

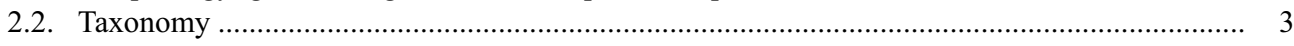

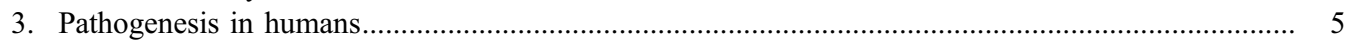

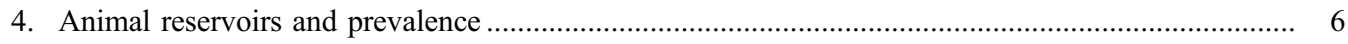

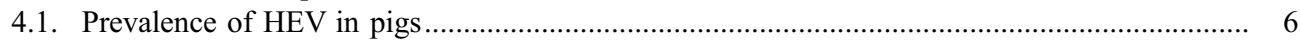

4.2. Prevalence of HEV in wild boars and deer ................................................................. 7

4.3. Prevalence of HEV in rodents and other animal species ...................................................... 8

5. Animal models and target organs....................................................................................... 9

5.1. Animal models and cross-species infection ................................................................. 9

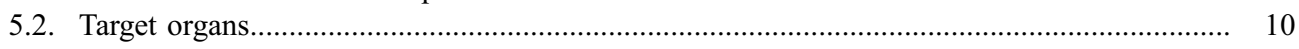

\footnotetext{
* Corresponding author: npavio@vet-alfort.fr

This is an Open Access article distributed under the terms of the Creative Commons Attribution-Noncommercial License (http://creativecommons.org/licenses/by-nc/3.0/), which permits unrestricted use, distribution, and reproduction in any noncommercial medium, provided the original work is properly cited.
} 
6. Zoonotic transmission

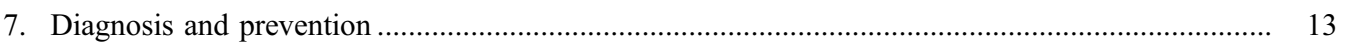

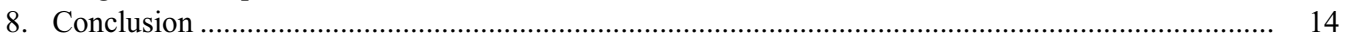

\section{INTRODUCTION}

Hepatitis E virus (HEV), the causative agent of acute human hepatitis $\mathrm{E}$, is responsible for an important public health disease in many developing countries of Asia and Africa [109]. The mortality rate associated with HEV infection ( 1 to $4 \%$ ) is higher than that of hepatitis A ( 0.1 to $2 \%$ ) [107], and can reach up to $20 \%$ during pregnancy [109]. HEV infection in developing countries is mostly a waterborne disease associated with large epidemics due to contamination of water and water supplies, and poor sanitation conditions $[6,109]$. In contrast, in industrialized countries, including many European countries, USA and Japan, acute hepatitis E occurs sporadically and the contamination pathways are still not fully understood [109]. Several lines of evidence, such as the absence of travel to endemic countries or different HEV strains involved in cases reported from industrialized countries than from developing countries [22], support an autochthonous origin of these sporadic cases. The particularity of HEV is that, among all known major hepatitis viruses (A, B, C and D), $\mathrm{HEV}$ is the only one with animal reservoirs. Swine HEV was first isolated and genetically characterized from pigs in the USA in 1997 [89], even though HEV antibodies and RNA were reportedly detected from pigs in the Kathmandu Valley of Nepal but the identity of the virus infecting the Nepalese pigs was not determined in that study [21]. More recently, an avian HEV was identified and characterized from chickens with Hepatitis-Splenomegaly (HS) syndrome in 2001 [46] in the USA as well. Besides swine and chickens, recently strains of HEV have been genetically identified from deer, mongooses, rabbits and rats [55, 99, 115, 141, 154]. Accumulating evidence indicates that hepatitis $\mathrm{E}$ is a zoonotic disease, and swine (and likely other animal species) are reservoirs. Swine and human strains of HEV are genetically closely related and, in some cases, indistinguishable
[78], and direct transmissions through the consumption of contaminated food products such as pork have been reported in Japan [149]. Thus, zoonotic transmission of hepatitis $E$ raises an important public health concern over food safety and zoonotic risk [95].

\section{HEPATITIS E VIRUS BIOLOGY AND CLASSIFICATION}

\subsection{Morphology, genome organization, and protein expression}

Hepatitis E virus belongs to the Hepeviridae family. It is a spherical, non-enveloped virus with an icosahedral symmetry [147]. Viral particles are approximately 32 to $34 \mathrm{~nm}$ in diameter and composed of a capsid protein (ORF2) assembled into a highly structured multimer (60 copies). The buyoant density of native virion particles, isolated from infected patient stools, is between 1.39 and $1.40 \mathrm{~g} / \mathrm{cm}^{3}$ in $\mathrm{CsCl}$ and its sedimentation coefficient is 183S [75]. The HEV capsid packages a single positivestranded RNA genome, which encodes 3 open reading frames (ORF). The RNA genome of HEV is capped at the $5^{\prime}$ end, and polyadelylated at the $3^{\prime}$ end $[48,116]$ with approximately $7.2 \mathrm{~kb}$ in length. The $5^{\prime}$ and $3^{\prime}$ extremities of the viral genome are non-coding regions probably involved in the regulation of viral translation and replication [135]. The ORF1, encompassing approximately two thirds of the viral genome, encodes non-structural proteins. Computer-based sequence analyses and predication, based upon the known motif of other positive-strand RNA viral proteins, have revealed several conserved putative functional domains in ORF1, including methyltrasferase, papain-like cystein protease, helicase, and RNA dependent RNA polymerase (RdRp) [68]. Due to the lack of efficient in vitro cell 
cultures for HEV replication, little is known regarding the translation and processing of the ORF1 polyprotein. It has been shown that when ORF1 is expressed in a baculovirus expression system, synthesis of several small proteins that correlate with the predictive motifs was observed [124]. However, when the ORF1 was expressed in bacteria or mammalian cells, no processing was observed [117]. Expression of RdRp fused to an enhanced green fluorescent protein (EGFP) in hepatoma cell line HepG2 has shown an endoplasmic reticulum (ER) localization suggesting that the HEV replication complex may be associated with the ER [110]. An ER transmembrane domain was identified in the RdRp region, and shown to interact with the $3^{\prime}$ end of HEV RNA [4, 110]. The second ORF, ORF2, is located at the $3^{\prime}$ end of the genome and encodes the capsid protein. ORF2 contains an ER signal peptide and 3 putative N-glycosylation sites [41]. When overexpressed in the human hepatoma cell line Huh7, the ORF2 protein is found to be glycosylated $(88 \mathrm{kDa})$ in the cytoplasm, after a retrotranslocation from the ER [132] and on the cell surface [150]. The ORF2 capsid protein interacts with the $5^{\prime}$ end of the viral RNA which probably plays a role in the viral RNA encapsidation [131]. ORF2 is putatively translated from a subgenomic RNA [108]. The reported numbers and sizes of HEV subgenomic RNA differed in infected livers and cell culture [103, 108]. Recently, a bicistronic subgenomic RNA, encoding both ORF2 and ORF3, was identified using an in vitro HEV replicon system [40]. The in vitro results were further verified with an in vivo swine model demonstrating that the third in-frame start codon (AUG) of HEV is the authentic initiation site for ORF3, and that ORF3 overlaps ORF2 but neither ORF2 nor ORF3 overlaps ORF1 [52]. The ORF3 encodes for a small phosphoprotein of 123 amino-acids associated with cytoskeleton, and may play a role in virus replication and virion morphogenesis [148]. ORF3 is necessary for viral infection in rhesus macaques in vivo but not in vitro [39]. In vitro, ORF2 and ORF3 proteins interact with each other, suggesting that ORF3 may play a role in viral assembly of de novo particles [142].
Since there is no in vitro model with robust viral replication, the virus life cycle remains hypothetical. Currently, no specific interaction with any cellular receptor has been described. Supposedly, after adsorption and uncoating, HEV RNA is probably first translated into non-structural proteins followed by the synthesis of genomic and subgenomic RNA [40, 108]. Replication complexes have been observed, in vitro, at the ER membrane [110]. Subsequently the translation of ORF2 and ORF3 proteins would occur, leading to the assembly of viral particles and the release of progeny virions. There is no evidence of a direct cytopathic effect caused by HEV [136], and it is more likely that the hepatocyte cytolysis observed during infection is mediated by the cellular immune response. Thus hepatitis E may be an immune-mediated disease [128].

\subsection{Taxonomy}

Based upon its superficial similarity in morphology and genome organization to the caliciviruses, HEV was originally classified in the Caliciviridae family [135]. The predicted putative functional motifs of HEV non-structural proteins are also similar to those of Rubella virus and alphaviruses of the Togaviridae family as well as to the plant furoviruses [68]. The HEV capping enzyme has properties very similar to those of viruses within the "alphaviruslike super group" [117]. A cap structure has been identified at the $5^{\prime}$ end of the HEV genome [60]. Although HEV shares several properties with these families, it has sufficient differences to be classified into a new Hepeviridae family [30]. HEV genomes vary significantly and consist of at least four major mammalian genotypes (1-4) and one avian HEV [46, 101] (Fig. 1). Mammalian HEV and avian HEV share only approximately $50-60 \%$ nucleotide sequence identity, thus avian HEV may constitute a separate new genus distinct from the current genus Hepevirus. Genotype 1 and genotype 2 mammalian strains are restricted in humans and mainly associated with large waterborne epidemics in endemic regions [78]; genotype 3 and 4 mammalian HEV strains are found both in human and other mammalian 


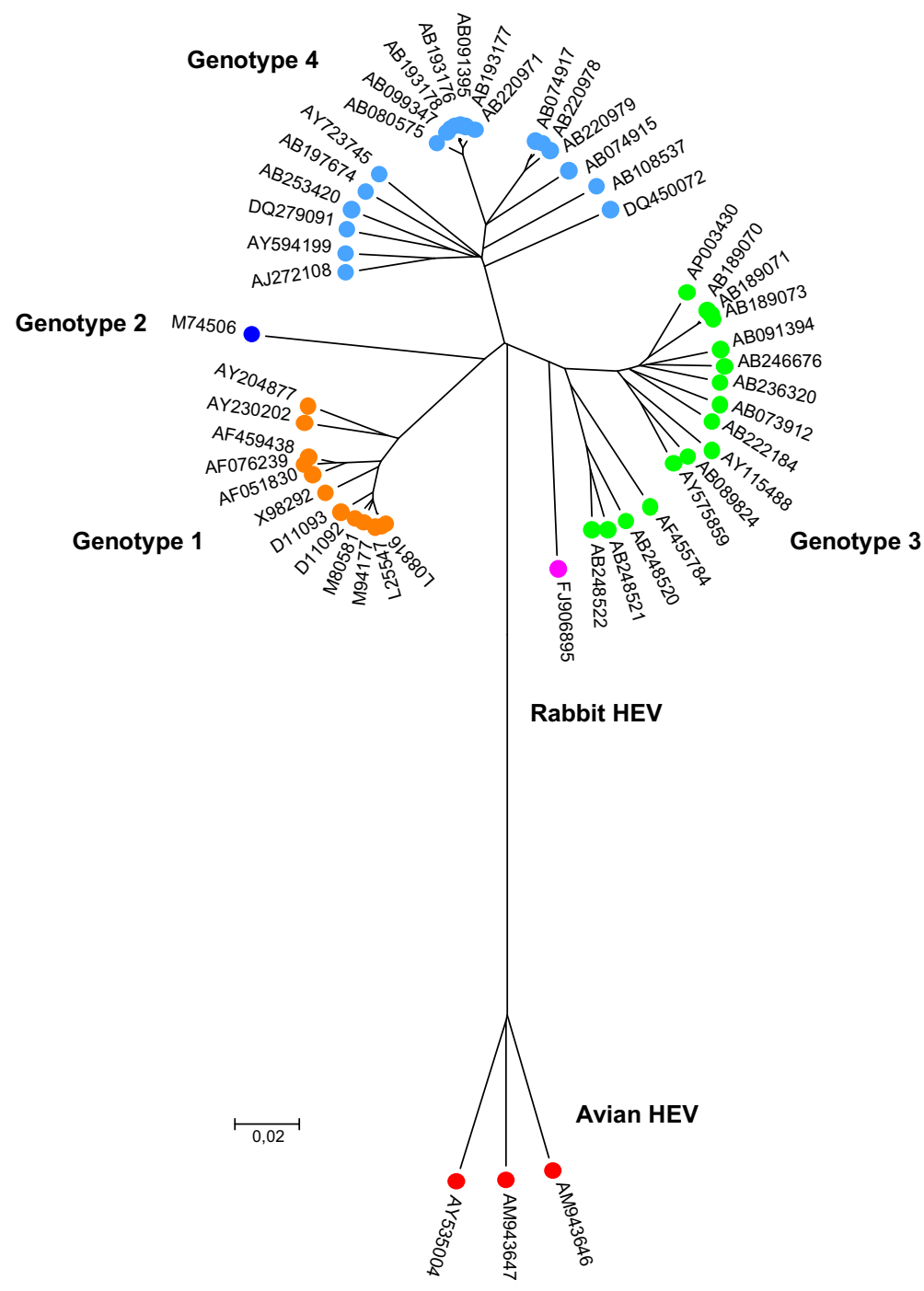

Figure 1. Phylogenetic tree representing 52 sequences of full length HEV genome retrieved from GenBank (accession numbers are indicated). Alignment was performed using ClustalW in MEGA 3.1. and the tree was built using the neighbor joining method with 1000 bootstrap replicates. (A color version of this figure is available at www.vetres.org.)

reservoirs (swine, wild boar, deer, mongooses) and are mainly responsible for sporadic cases of hepatitis E. Genotype 3 is found mainly in Europe, the USA and Japan, and genotype 4 has been identified mainly in Asia (China, Japan and India) [78] and occasionally in Europe (Germany and one possible case imported from Vietnam to Spain) [37, 144]. In addition to the prototype avian HEV strains from the USA, several genetically-distinct strains of avian HEV have been identified recently from chickens in Australia and Europe (Hungary and Spain), and there exist at least three genotypes of avian HEV worldwide 
[11, 104] (Fig. 1). Very recently, a novel strain of HEV was isolated from farm rabbits in China. The rabbit HEV is most closely related to HEV genotype 3 with approximately $82 \%$ of nucleotide sequence homology, suggesting that rabbit HEV may be a variant of genotype 3 [154] (Fig. 1). Currently there is little information regarding the host range and zoonotic potential of this rabbit HEV. Since the rabbit $\mathrm{HEV}$ is a variant of genotype 3 , it is possible that the rabbit HEV may also have the ability to infect across species. More recently, a new hepatitis E-like virus was identified in the feces of wild rats in Germany. Partial sequence analyses showed that the rat HEV only shares approximately $59.9 \%$ and $49.9 \%$ sequence identities, respectively, with known human and avian $\mathrm{HEV}$, suggesting that rat HEV may represent an additional new HEV genotype within the hepevirus genus [55]. The complete genomic sequence of the rat HEV is needed for a definitive classification. It remains to be determined whether or not rat HEV can infect humans.

\section{PATHOGENESIS IN HUMANS}

Hepatitis E is transmitted by the fecal-oral route, usually via the consumption of contaminated water or food. In contrast to hepatitis A virus and other enteric viruses, human-tohuman transmission of HEV is rare [1]. From a clinical point of view, hepatitis $\mathrm{E}$ is similar to hepatitis A, with acute self-limiting and symptomatic disease that varies in severity from subclinical to fulminant [29]. Incubation time ranges from 2 weeks to 2 months with an average of 40 days, viremia is transient and occurs mainly during the prodromic phase, and disappears at the onset of clinical symptoms. Fecal excretion of the virus begins a few days ( 5 days on average) prior to jaundice, and regresses at the onset of jaundice within 2 to 3 weeks [2]. Most autochtonous cases of hepatitis $\mathrm{E}$ are reported in middle-aged and elderly men [109]. Fulminant hepatitis is observed in $1-4 \%$ of the cases which is higher than hepatitis A [69]. The mortality rate reaches up to $20 \%$ in pregnant woman in some endemic areas (northern and central India, Pakistan)
[53, 67]. In other countries such as Egypt or southern India, pregnant women are not significantly at higher risk to develop fulminant hepatic failure (FHF) [100, 129]. More recently, a 20-year study of the association of HEV-associated acute liver failure with pregnancy revealed that the mortality of pregnant patients is similar to that of nonpregnant women [9]. Pregnancy is a poor prognostic factor for a patient with acute liver failure associated or not associated with HEV infection [9]. Thus, various factors such as HEV strains (genotype or subtypes), viral load, or other co-infections might play a role in pathogenesis [112]. It appears that, compared to genotypes 1 and 2 , the genotype 3 and 4 strains are less pathogenic in humans. Therefore, the differences of HEV genotypes in different geographical regions might explain the severity of infection during pregnancy. However, in Egypt and southern India where genotype $1 \mathrm{HEV}$ is prevalent, low mortality rates are observed during pregnancy, thus suggesting that other factors may be involved in the observed high mortality rate during pregnancy in some regions [100]. To our knowledge, no cases of fulminant hepatitis $\mathrm{E}$ associated to genotype 3 infection during pregnancy have been reported [5].

More recently, other clinical forms of HEV diseases have been observed in patients under immunosuppressive conditions, such as transplant recipients [63], or patients suffering from leukemia [71]. Some of these patients developed chronic HEV infection progressing to cirrhosis [62]. This clearly suggests that the atypical clinical and virological outcome for HEV infection in these cases could be related to immunosuppressive treatments, which might have resulted in suboptimal anti-HEV-specific immune responses and subsequent viral persistence. Such a hypothesis has been evocated by Kamar et al. [63] who found significantly reduced CD2-, CD3-, and CD4-lymphocyte counts in patients with chronic disease, and in populations at risk of developing FHF. Another population that might be at risk of chronic HEV infection are HIV patients with an advanced stage of immunodeficiency. However, so far there has been no increased prevalence of HEV infection observed in that population $[79,113]$. Only a 
few cases of acute hepatitis $\mathrm{E}$ have been reported in HIV patients [24], including a pregnant woman who recovered completely [139].

In non-endemic regions, the number of hepatitis $\mathrm{E}$ cases in humans seems to be on the rise largely due to an increasing interest in this disease. Recent efforts have been done to evaluate the reliability of HEV diagnostic tools [10, 74]. One retrospective study has reported that the incidence of hepatitis E in France was stable over a period of 5 years, suggesting that hepatitis $\mathrm{E}$ is generally under-diagnosed [80]. Clinicians need better awareness of this disease in order to accurately determine the incidence of $\mathrm{HEV}$ infection.

\section{ANIMAL RESERVOIRS AND PREVALENCE}

Domestic pigs and wild boars are the main animal reservoir for the genotypes 3 and 4 strains of HEV worldwide [95]. Besides pigs, anti-HEV antibodies have also been detected in many other animal species including deer, rats, dogs, cats, mongooses, cows, sheep, goats, avian species, rabbits and horses [55, 99, 115, $121,141,152,154]$ suggesting that these animal species are exposed to HEV or to a closely related agent. While strains of HEV genotype 3 and/or 4 have been genetically identified in the wild boar, deer, mongoose and rabbit [154], the source of seropositivity in other animals, with the exception of chickens [46] and rats [55] remains unknown [95].

\subsection{Prevalence of HEV in pigs}

Several descriptive studies on HEV prevalence have been carried out in swine herds in different countries. The nature of the collected information is very diverse among studies: detection of different classes of anti-HEV antibodies IgG and sometimes IgM and/or IgA [36, 72, 97, 134], detection of viral RNA by RT-PCR in serum samples [134], feces from individual pigs or slurry, $[49,119]$, or commercial liver from grocery stores [33, 57, 149]. All serological studies converged on a very wide distribution of $\mathrm{HEV}$ in swine herds. If we consider that a herd is positive when at least one individual is identified as being seropositive, the following was found: $100 \%(15 / 15)$ were positive in the USA [89], 90\% (20/22) in New Zealand [38], 46\% (23/50) in Laos [14], 100\% (10/10) in Mexico [25], and 98\% (40/41) in Spain [125]. A retrospective study performed in Spain, including 208 herds followed since 1985, shows that endemic HEV infection in pigs is not a recent phenomenon $(204 / 208=98 \%)$ [20]. At the individual level, in pigs of 6 months of age, the average seroprevalence varied greatly from study to study: $56 \%$ of HEV-positive pigs in Japan [134], $23 \%$ in Argentina [97], 81\% in Brazil [42], and $51 \%$ in Laos [14]. The observed high variability of seroprevalence rate results from important differences within each herd (4 to $58 \%$ for the Argentine study [97], 15 to $100 \%$ for the Brazilian study [42]). Strong fluctuations in seroprevalence rate are also observed according to the animal's age, with pigs older than 4 months generally being higher [134]. This observation is consistent with a natural HEV infection of pigs between 10 and 12 weeks of age. In a prospective study of a swine herd in the USA, the majority of swine became infected at the age of 2 to 4 months [89], consistent with the high seroprevalence rate in pigs older than 4 months old. The IgG anti-HEV seroprevalence rate in sows is higher, ranging from 60 to $73 \%[38,125]$.

The detection of HEV RNA in sera shows a very strong influence of the age of animals as shown in a Japanese study [134]. The highest number of viremic animals is observed at 3 months of age ( $32 / 310$ positive). In this study, none of the 136 animals tested at 6 months of age were positive. In the Netherlands, a survey was performed in 97 herds with 20 weeks old pigs: 53 herds $(55 \%)$ contained at least one animal excreting the virus in feces [119]. Faecal excretion of HEV seems to heavily depend on the age of the animals, peaking at 18 weeks of age $(86 \%$ of the pigs with fecal virus shedding), and decreasing afterwards to $41 \%$ at the age of slaughter, as shown in a study performed in Canada [72]. In accordance with these data, the results obtained in Spain [36] show the highest number of positive pigs 


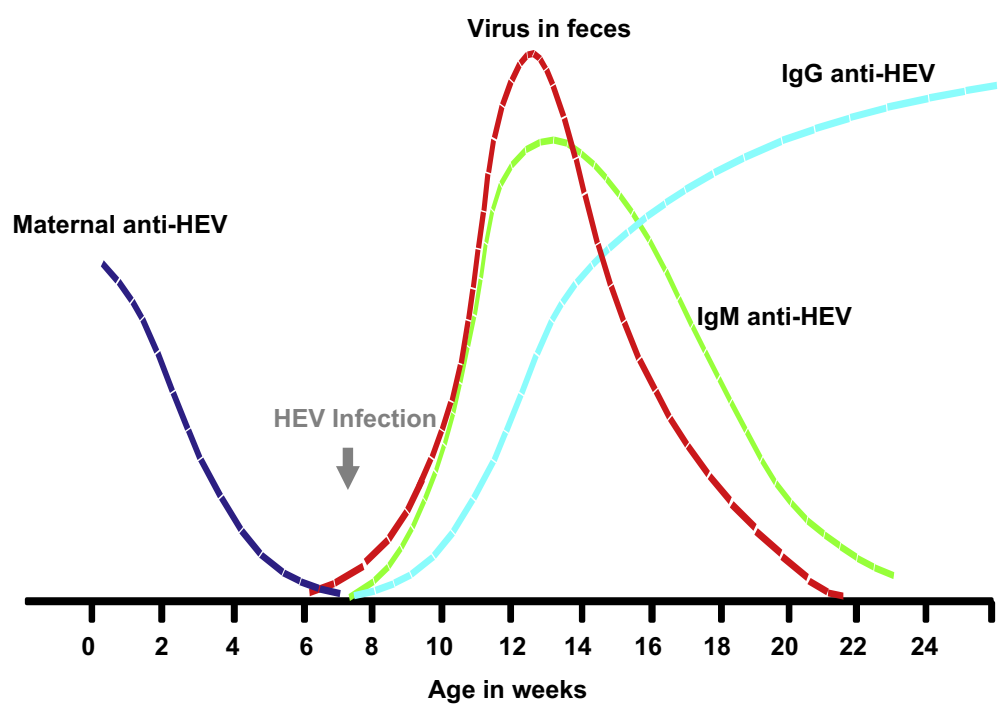

Figure 2. Approximation of the natural time course of HEV infection in pigs. Representation of the kinetics of seroconversion: maternal anti-HEV antibodies (dark blue), IgM anti-HEV (green), IgG anti-HEV (light blue) and fecal excretion of HEV (red) in pigs infected naturally. Adapted from the results presented in Section 4.1: prevalence of HEV in pigs). (A color version of this figure is available at www.vetres.org.)

(12/20) with fecal virus shedding at 13-16 weeks of age, and the results from the United Kingdom [88] show the highest number of animals with faecal excretion at 10-12 weeks of age (22\%), decreasing to $4 \%$ for pigs older than 22 weeks of age. In the various studies carried out in Europe, the HEV strains identified that all belong to genotype $3[88,125]$.

Under natural conditions of infection, the dynamics of HEV infection is similar to what is described for most viral infections in pigs: acquisition of passive immunity through colostrum absorption ( $60 \%$ of the piglets), progressive decline of these passive antibodies at 8-10 weeks of age, then seroconversion between 14 and 17 weeks of age (Fig. 2) corresponding to the peak of viremia observed at 15 weeks of age ( $40 \%$ of animals) [26]. In a Spanish study, the percentage of viremic pigs increased from 9 weeks to 15 weeks of age and gradually decreased towards slaughter age [26]. The IgM anti-HEV increased from 9 weeks of age, and approximately $100 \%$ of the pigs studied $(n=16)$ were IgG anti-HEV-positive at 22 weeks of age (Fig. 2). This dynamics observed in a Spanish herd is also in accordance with what was observed in Japan where the peak of faecal virus excretion was between 1 and 3 months of age ( 75 to $100 \%$ of the animals) then decreased to $7 \%$ of the animals at 5-6 months of age [98] (Fig. 2). The seroprevalence observed at the end of fattening reveals an effective transmission of the virus between the animals from the same fence. This was confirmed by the experimental estimation of the basic reproduction ratio $\left(R_{0}\right)$ of $\mathrm{HEV}$ which is estimated to 8.8 [17], revealing the theoretical possibility for 1 infected pig to infect more than 8 animals of a naive population during its infectious period [17].

\subsection{Prevalence of HEV in wild boars and deer}

A few studies report the presence of HEV in wild boars and deer in Europe and Japan [27, $58,61,81,86,96,115,120,122,127,141]$. The seroprevalence rates observed in wild boars are variable from 9 to $71 \%$, and in deer from 2 to $35 \%$ (Tab. I). The prevalence of HEV RNA ranges from 3 to $25 \%$ in wild boars 
Table I. HEV in wild boars and deer.

\begin{tabular}{lccccc}
\hline Country & Animal species & Serology & HEV RNA genotype 3 & Type of sample & Reference \\
\hline Japan & Yezo deer & $34.8 \%(181 / 520)$ & nd & Serum & {$[141]$} \\
Japan & Wild boar & $9 \%(n=35)$ & nd & Serum & {$[127]$} \\
& Wild deer & $2 \%(n=117)$ & nd & Serum & \\
Japan & Boar & & & & {$[96]$} \\
& Wild-caught & $25 \%(100 / 392)$ & nd & Serum & \\
& Bred & $71 \%(10 / 14)$ & $3 \%$ & Serum & \\
Hungary & Wild boar & nd & $12.2 \%(9 / 74)$ & Liver & {$[115]$} \\
& Roe deer & nd & $34.4 \%(11 / 32)$ & Liver & \\
Germany & Wild boar & nd & $5.3 \%$ & Serum & {$[61]$} \\
Germany & Wild boar & nd & $15 \%$ & Liver & {$[122]$} \\
Italy & Wild boar & nd & $25 \%(22 / 88)$ & Bile & {$[81]$} \\
Spain & Wild boar & $42.7 \%$ & $19.6 \%$ & Serum & {$[27]$} \\
The Netherlands & Wild boar & nd & $4 \%$ & Feces & {$[120]$} \\
France & Wild boar & nd & $2.5 \%(7 / 285)$ & Liver & {$[58]$} \\
\hline
\end{tabular}

nd: Not determined.

(Tab. I). More recently, a Hungarian study reported that approximately $34 \%$ of deer livers were positive for HEV RNA (11/32) (Tab. I).

In these studies, reporting on divergent prevalence, sample sizes were generally small and of various origins such as the liver, sera, bile, and feces (Tab. I). There were limited data on the age of the animals tested, which makes it difficult to evaluate the real infection level of these animal species. The HEV strains amplified from these animal species were of genotype 3 or 4 and were genetically very closely related to human and swine strains described in the same geographic regions [115, 133], and thus suggesting possible interspecies transmission.

The presence of genotype $3 \mathrm{HEV}$ in the Japanese mongoose $(8.3 \%, 7 / 84)$ has been reported in southern Japan (Okinawa) [77, 99], although no human case associated with this reservoir has been reported so far.

\subsection{Prevalence of HEV in rodents and other animal species}

Rodents are present in both urban and rural areas and thus, may play an important role in HEV transmission. Rats from both urban and rural areas have been detected to be seropositive for IgG anti-HEV. It has been shown that about $77 \%$ of the rats from Maryland, $90 \%$ from
Hawaii and 44\% from Louisiana were positive for IgG anti-HEV [59]. The IgG anti-HEV prevalence rate increases in parallel with the estimated age of the rats. All three species of wild rats (Rattus norvegicus, Rattus rattus and Rattus exulans) tested in the study were seropositive. In another study, 26 different species of rodents caught in the USA were tested for IgG anti-HEV prevalence, and the highest prevalence rate was found in the genus Rattus (59.7\%). Rodents caught in an urban area had a higher IgG anti-HEV prevalence rate than rodents caught from rural areas [32]. In Japan, it is reported that approximately $32 \%$ of Norway rats (R. norvegicus) and $13 \%$ of black rats ( $R$. rattus) were seropositive for IgG anti-HEV [47]. The seroprevalence of HEV antibodies in different rodent populations varied in different geographic regions [94]. These results indicated that there is a widespread infection of rats by HEV in different countries. The recent genetic identification of a strain of HEV from rats in Germany [55] confirms these serological findings. It appears that the rat $\mathrm{HEV}$ is genetically distinct from the known strains of mammalian HEV. It remains unknown whether or not the rat HEV has the ability to cross the species barrier and infect humans.

Immunoglobulin $\mathrm{G}$ anti-HEV was also reportedly detected in dogs in Vietnam and India, in cows from India, Somali, Tajikistan, 
Turkmenistan, and Ukraine, and in sheep and goats from Turkmenistan [7, 140]. However, the source of seropositivity in these animal species could not be definitively identified thus far. Nevertheless, the existence of a population of animal species positive for IgG anti-HEV suggests that pigs may not be the only animal reservoir for HEV.

\section{ANIMAL MODELS AND TARGET ORGANS}

\subsection{Animal models and cross-species infection}

Animal models have been developed to study HEV replication and pathogenesis. One animal model was developed in non-human primates: cynomolgus macaque (Macaca fascicularis) [91] or less frequently chimpanzee [87]. The non-human primates were used mainly to study genotypes 1 and $2 \mathrm{HEV}$ strains. A second animal model was developed in pigs [90] in which genotypes 3 and 4 replicate efficiently. Both non-human primate and pig models were used to demonstrate cross-species infections or extrahepatic sites of HEV replication [145]. More recently, a third animal model was developed in specific-pathogen-free chickens [12] to study the avian strains of HEV and the HS syndrome associated with avian HEV infection [13].

The first two models of HEV infection (nonhuman primates and swine) represent limited clinical interest for viral pathogenesis studies, the animals remain asymptomatic, only viremia with virus shedding in feces and seroconversion were observed $[3,45]$. Very moderate increases in hepatic enzyme activities and minor hepatic pathological lesions were occasionally observed [3].

Initially, the macaque model was developed to study genotype 1 and $2 \mathrm{HEV}$ strains isolated from humans, although non-human primates are susceptible to all 4 genotypes of HEV [95]. This model was used to demonstrate that cross-species infections occur, since inoculation of rhesus macaques (Macaca mulatta) with swine HEV genotype 3 or 4 strains led to productive infections [8, 91]. Slight elevation of serum liver enzymes, fecal excretion and seroconversion to IgG anti-HEV were observed [8]. Comparison of pathological lesion profiles after infection with genotype 3 human or swine HEV did not reveal major differences, suggesting that genotype 3 or $4 \mathrm{HEV}$ strains have no specific host restriction between swine and primates [91]. However, an attempt to experimentally infect rhesus macaques with the avian HEV strain failed, suggesting that the avian HEV strain represents a limited risk for human infection [51]. Swine are naturally infected by genotype 3 or $4 \mathrm{HEV}$ but are not susceptible to infections by genotype 1 of the Pakistani strain (Sar-55) of HEV nor to infection with the Mexican strain of genotype 2 [90]. The molecular mechanism underlying this host restriction remains unknown. Genotype 3 and $4 \mathrm{HEV}$ strains isolated from humans are infectious when inoculated into pigs $[35,91]$. The comparison of pathological lesions between the genotype 3 swine and human HEV strains did not reveal a major difference [45]. The experimental infection of pregnant gilts with genotype 3 swine HEV did not lead to any fulminant hepatitis, abortion or vertical transmission [64]. It is hypothesized that the genotype 3 swine HEV or human HEV is less virulent than genotype 1 or $2 \mathrm{HEV}$ [109].

It has been demonstrated that chickens can serve as a good model for the study of avian HEV replication and pathogenesis [12]. Unlike the swine and non-human primate models in which reproduction of $\mathrm{HEV}$ infection by the oral route of inoculation has been difficult, chickens can be readily infected with avian HEV via the natural oral route [12]. Evidence of vertical transmission has been demonstrated in the chicken model infected with avian HEV. Avian HEV detected in chicken egg white was found to be infectious, although no virus was detected in samples collected from the hatched chicks, suggesting that avian HEV could not complete the vertical transmission cycle [43]. The host range of avian HEV appears to be limited. Although the avian HEV can infect turkeys [130], attempts to infect pigs and rhesus monkeys with avian HEV were unsuccessful $^{1}$ [51]. In addition, a genotype 3

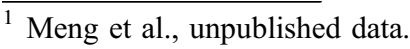


swine HEV failed to infect chickens under experimental conditions ${ }^{2}$.

\subsection{Target organs}

The main target organ of HEV replication in the pig is the liver but HEV infection is totally unapparent in pigs [73]. Mild hepatic lesions characteristic of hepatitis have been described in experimentally-infected pigs [45], and in naturally-infected pigs in the USA [89] and in Spain in the context of post-weaning multisystemic wasting syndrome [82].

Studies on HEV dissemination in pigs infected experimentally by intravenous inoculation (IV) have identified extrahepatic sites of HEV replication. As expected, evidence of viral replication was found in the liver but also in the colon, lymph nodes (mesenteric and hepatic) and spleen for up to 20-27 days post-inoculation [145]. The virus RNA was also detected in the stomach, small intestine, spleen, kidney, salivary glands, tonsils or lungs (14 days postinoculation). Viral RNA, but no viral replication, was detected in the muscles at 14 days post-infection at which time the pigs also had viremia [145]. In a recent study, comparing the course of HEV infection in pigs via contact-infection or IV inoculation, the presence of HEV RNA was confirmed in Longissimus, Biceps, Femoris and Iliopsoas muscles at 27 days post-inoculation in IV-inoculated pigs and 31 days in contact-infected pigs [18]. These HEV RNA-positive organs may result from viremia, rather than from active virus replication, but they may still represent a risk of HEV contamination of pork products. It has been shown that the results obtained after contact-infection or IV-inoculation of pigs were different, suggesting that the route of HEV infection may influence viral dissemination. HEV was found in urine after contact infection $(3 / 5)$ but not in IV-inoculated pigs (0/5) [18]. The presence of HEV in urine, in addition to feces, may contribute to the high transmissibility of HEV between animals. The IV route is commonly utilized in experimental infection since it is more efficient than fecal-oral or

\footnotetext{
${ }^{2}$ Sun and Meng, unpublished data.
}

contact-exposure routes but may not reflect natural HEV infection [65]. By using the chicken model, Billam et al. reported on the identification of extrahepatic sites of HEV replication in animals after experimental infection via the natural oral route of HEV inoculation [13]. In addition to the liver, replicative HEV RNA was also detected in gastrointestinal tissues, including the colorectal, cecal, jejunal, ileal, duodenal, and cecal tonsil tissues [13].

The omnipresence of HEV infection in pigs and the detection of HEV replication in the liver raised the concern for the presence of HEV in slaughtered pigs and in livers sold in grocery stores. Several studies reported the detection of HEV RNA in commercial pig livers: $1.9 \%$ (7/363) in Japan (genotypes 3 and 4) [149]; $6.5 \%(4 / 62)$ in the Netherlands (genotype 3) [15]; $10.8 \%$ in Korea (genotypes 3), samples collected between 1995 and 2004 [57], $0.83 \%$ $(2 / 240)$ in India (genotype 4) [70] and in 11\% in the USA [33] (genotype 3). In the last study, the presence of infectious virus in commercial livers was confirmed by inoculation of HEV RNA-positive liver homogenate into pigs [33], raising the possibility of human infection through consumption of contaminated pork products. In order to study if heating (cooking) would inactivate HEV, small pieces of HEV RNA-positive livers were cooked at different temperatures and the residual infectious virus was measured in a swine bioassay [34]. The results showed that deep fried $(5 \mathrm{~min}$ at $191{ }^{\circ} \mathrm{C}$ ) or boiling $(5 \mathrm{~min})$ can effectively inactivate $\mathrm{HEV}$, although a treatment of $1 \mathrm{~h}$ at $56{ }^{\circ} \mathrm{C}$ did not inactivate HEV [34]. These results underline that contaminated food products, if consumed raw or undercooked, could potentially transmit the virus to humans. Therefore, some food preparations, such as mid-dry liver sausage, should be consumed after cooking to minimize potential HEV infection.

\section{ZOONOTIC TRANSMISSION}

Two cases of confirmed zoonotic transmission of HEV through the consumption of contaminated animal food products have been reported in Japan (Tab. II, upper) [76, 138]. 
Table II. Cases of zoonotic HEV transmission through consumption of contaminated foodstuffs.

\begin{tabular}{|c|c|c|c|c|c|}
\hline $\begin{array}{l}\text { No. of cases/ } \\
\text { incubation time }\end{array}$ & Animal species & $\begin{array}{l}\text { Cooking/ } \\
\text { recipe }\end{array}$ & Genotype & $\begin{array}{l}\text { Elements in favor of } \\
\text { a zoonotic transmission }\end{array}$ & $\begin{array}{l}\text { Reference } \\
\text { country }\end{array}$ \\
\hline \multicolumn{6}{|l|}{ Confirmed } \\
\hline $\begin{array}{l}4 \tilde{\|}_{\text {days }} \\
40 \text { d }\end{array}$ & Sika deer & $\begin{array}{l}\text { Slice of raw } \\
\text { meat (sushi) }\end{array}$ & 3 & $\begin{array}{c}100 \% \text { of sequence } \\
\text { homology between } \\
\text { patient and meat } \\
\text { (frozen). } 10^{5} \mathrm{GE} / \mathrm{g} \text { meat }\end{array}$ & [138] Japan \\
\hline $\begin{array}{l}1 \text { 巾 } \\
60 \text { days }\end{array}$ & Wild boar & Grilled & 3 & $\begin{array}{c}\text { Almost } 100 \%(99.95) \\
\text { of sequence homology } \\
\text { between patient } \\
\text { and meat (frozen). }\end{array}$ & [76] Japan \\
\hline
\end{tabular}

Putative
$2 \prod^{\pi}$ to 60 days

4
Share and consumption of the same meal.
2 patients $\operatorname{IgM}$ and $\operatorname{IgG}$ positive and one of the two patients was HEV RNA positive.

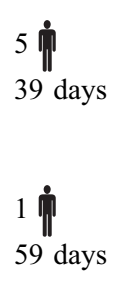

Wild boar

Grilled

(Barbecue)

Wild boar

Grilled marinated meat (Barbecue)
3
The patient was IgM, IgG and

[85] Japan
On 12 persons attending [137] Japan the same meal:
8/12 $\operatorname{IgM}+, 11 / 12 \operatorname{IgG}+$ and 2/12 RNA +

HEV RNA positive and 1 person with high anti-HEV IgM had shared the same meal.
10 i் 14 to 60 days
Pork
Grilled liver, undercooked, rare
3,4

9/10 patient had consumed raw or undercooked pig liver earlier.

In these two cases, clinical symptoms occur 40 or 60 days after consumption of Sika deer (sushi) or wild boar (grilled) meat. In both cases, HEV RNA was successfully amplified in the patients as well as in the leftover frozen animal meat. The HEV viral sequences recovered from the patients and from the leftover frozen meats are either identical or near identical with $99.95 \%$ identity, confirming the zoonotic nature of transmission through the consumption of animal food products. In one of these cases, the level of HEV contamination of the meat was estimated by quantitative RT-PCR to be approximately $10^{5}$ genome equivalents (GE) per gram of meat. There was no indication on the quantity of meat ingested by the patient nor the type of meat (liver or muscle) involved [138].

In four other studies in Japan, HEV infection via the consumption of contaminated food was supported by several pieces of evidence. In all cases, hepatitis E were observed 14 to 60 days after consumption of raw or under cooked pork products [83, 85, 137, 149]: wild boar barbecue, raw wild boar liver, grilled or uncooked pork liver (Tab. II, bottom). IgM and/or IgG antibodies and/or HEV RNA were detected in patients who shared the same meal with the index-case(s) [83, 85, 137, 149]. Very recently in France, a case-control study showed that 
eating raw sausage made with pork liver is linked with autochtonous hepatitis $\mathrm{E}$ human cases $^{3}$. Thus, among the possible contamination pathways of $\mathrm{HEV}$, contaminated food must be seriously considered. A recent German study also supports a foodborne origin of HEV infection [144]. A case-control study was performed and the risk factors found, independently associated with autochthonous HEV infection, were offal consumption ( $41 \%$ versus $19 \%$ ) and wildboar meat consumption ( $20 \%$ versus $7 \%$ ). The meat products implicated should be investigated for the presence of HEV. These data would contribute to define preventive measures [144].

Another possible way of HEV exposure is through direct contact with animals. Higher anti-HEV antibody prevalences within individuals in close contact with pigs have been reported: slaughterhouse staff, veterinarians and pig breeders. A survey in a cohort of 295 veterinarians from 8 American states showed an antibody prevalence of $27 \%$ in swine veterinarians versus $16 \%$ in the general population [93]. Both swine veterinarians and normal blood donors, from traditionally-major swineproducing states are more likely to be seropositive than subjects from traditionally non-major swine-producing states [93]. A limited number of pig handlers in two endemic countries (China and Thailand) were also tested for IgG antiHEV prevalence, and most of them were found to be seropositive for HEV [92]. In Sweden, a study also showed a high prevalence of HEV antibodies within the pig breeders' population (13\%) [102]. To support these data, a Bayesian approach was used in the Netherlands to estimate a seroprevalence rate of approximately $11 \%$ for swine veterinarians, $6 \%$ for non-swine veterinarians and $2 \%$ for the general population [16]. In Moldova, it has been reported that approximately $51 \%$ of swine farmers were IgG anti-HEV positive whereas only $25 \%$ of control subjects with no occupational exposure to swine were seropositive. Swine

\footnotetext{
${ }^{3}$ Colson P., Gerolami R., Hepatitis E - France: (Marseille) pig liver sausage, ProMED-mail PRO/ AH/EDR 2009; 17 Sep: 20090917.3267 [on line] http://www.promedmail.org [consulted 22 Feb 2010].
}

farmers with a history of cleaning barns or assisting pig birth were 2.46 times more likely to be seropositive than controls [28]. In North Carolina, Withers et al. reported that swine workers had a 4.5-fold higher anti-HEV prevalence $(10.9 \%)$ than the controls $(2.4 \%)$ [146].

Recently, an acute hepatitis E was reported in a person who had been given a pet pig 2 months before the onset of symptoms. HEV sequences closely related to the sequence recovered from the patient were identified from the animal, and shown to belong to the genotype 3 HEV strain with 94\% nucleotide sequence identity [111]. Thus, contact with animals and especially swine increase the risk of $\mathrm{HEV}$ exposure.

The possible source of $\mathrm{HEV}$ infection in these cases could be feces or manure, since large amounts of virus can be excreted in feces [66]. One study has investigated the presence of $\mathrm{HEV}$ in manure storage facilities (earthen lagoons or concrete pits) [66]. HEV-contaminated effluents were detected in seven of the 28 farms investigated with up to $10^{3} \mathrm{GE}$ of HEV genomic RNA per $60 \mathrm{~mL}$ of pit samples. The presence of infectious virus was confirmed by a swine bioassay [66]. None of the water samples tested in the farm vicinity was positive [66]. Manure storage and spreading may vary from country to country, and thus further investigations should be done to evaluate this possible contamination pathway. Furthermore, a recent study has investigated zoonotic, foodborne, or water-borne origin of genotype 3 HEV infections in people in The Netherlands. Interestingly, $17 \%$ of surface water samples were found positive [120]. The possible HEV contamination of the environment is thus of concern and must be further studied.

To evaluate the risk associated with zoonotic HEV transmission, a piece of very important data such as a dose-response model for HEV, is still missing. Since there is no efficient in vitro cell culture model to propagate $\mathrm{HEV}$, little is known on HEV infectivity. The number of infectious particles in correlation with the number of genome equivalent (GE, estimated by semi-quantitative RT-PCR) has been estimated using the pig model [65]. A titration of a suspension containing $10^{6}$ (GE) was 
performed and it corresponds to approximately $10^{4.5} 50 \%$ pig infectious dose $\left(\mathrm{PID}_{50}\right)$ [65]. Thus, one $\mathrm{PID}_{50}$ corresponds to approximately $10^{1.5} \mathrm{GE}$, but IV inoculation is not a natural route of HEV transmission, except in cases of blood transfusion [23, 84]. Another study has shown that pigs orally infected with $10^{5.3} \mathrm{GE}$ had seroconverted, or excreted virus in $25 \%$ of the cases (4/16) [19]. Thus, the data suggest that infection by HEV genotype 3 requires high copy numbers of GE in animals. This observation might be different for genotypes 1 and 2 in humans, although this can serve as an indicator.

\section{DIAGNOSIS AND PREVENTION}

Viral hepatitis $\mathrm{E}$ is similar to the other types of acute viral hepatitis. Usually HEV markers are tested after the patients are found to be negative for the following tests: IgM antibodies to hepatitis A virus; AgHBs, anti-HBc IgM, and DNA to hepatitis B; antibodies and RNA to hepatitis $\mathrm{C}$ virus; IgM antibodies for Cytomegalovirus and Epstein Barr Virus; anti-nuclear, anti smooth muscle and anti-LKM-1 antibodies [114]. Acute hepatitis E diagnosis is based on a ten times higher ALT elevation than the normal value and the presence of increasing anti-HEV IgG titers and/or the presence of anti-HEV IgM and/or HEV RNA in the serum and/or stool samples [114]. Several diagnostic kits for HEV serology in humans are available and have been validated. Detection of antiHEV IgM with the recent commercial kits seems to be specific and reliable [74]. Many RT-PCR and quantitative RT-PCR have been developed for HEV RNA amplification in different laboratories, but no commercial kit is available [56, 123, 153].

Since HEV infection is asymptomatic in swine, HEV diagnosis is not performed routinely in pigs. HEV serology or detection of HEV RNA is performed only in research laboratories that have developed assays adapted to swine [14, 20, 26, 31, 54, 105]. HEV genotype 3 and 4 strains present in animals are genetically very similar to human HEV genotypes 3 and 4, thus they can not be distinguished by specific RT-PCR amplification [25, 44,
56, 143]. HEV detection in swine herds is important to measure the level of contamination of this large animal reservoir especially in countries with industrial swine farming. Sensitive and specific RT-PCR assays have been developed in independent laboratories to detect all 4 mammalian genotypes of HEV $[25,49,143]$. More recently, a nested broadspectrum RT-PCR capable of detecting different HEV types, including the four mammal genotypes, chicken strains and the new HEV type of rats was reported, and this assay was successfully used to amplify the rat HEV [55]. Since only one serotype of HEV has been described, detection of anti-HEV antibodies in swine can be performed using commercial kits for humans adapted to swine or in-house tests with genotype 1 or $3 \mathrm{HEV}$ antigens in ELISA [31, 54, $105,118]$. Although various HEV seroprevalence rates in swine have been reported, the tests used have not been validated due to the absence of appropriate "gold standards" [14, 20, 26, 54, 106, 151].

Currently, avian HEV diagnosis is primarily based on detection of avian HEV RNA by RT-PCR or detection of avian HEV antibodies by ELISA [50, 104]. However, the sensitivity and specificity of these assays are not known. Avian HEV capsid protein has been expressed and used in an ELISA to detect avian HEV antibodies in chickens [50, 104]. Avian HEVspecific RT-PCR assays have also been successfully developed for the detection of avian HEV infections in chickens [50, 104]. However, the specificity of the RT-PCR assays in detecting avian HEV strains in chickens from different geographic regions is not known, since avian HEV strains identified from chickens in different geographic regions are genetically heterogenic.

Efforts on HEV prevention concern mostly sanitation in developing countries, to limit contamination of drinking water by infected materials. Particular information and surveillance must be taken with populations at higher risk of fulminant hepatitis such as pregnant women and people with underlying liver conditions. In industrialized countries, where zoonotic transmissions may be the main route of hepatitis $\mathrm{E}$ infection, consumers of raw or undercooked meat should be advised on the potential risk. 
Populations at risk such as pregnant women, transplant recipients and individuals with underlying liver conditions should be informed on the possible risk of consuming raw pork, deer or wild boar meat or having contact with infected pigs. In the same line, pig handlers and veterinarians who are exposed to $\mathrm{HEV}$, must take hygienic measures after handling the animals. In swine, since HEV seems very contagious between animals [17], further investigation must be performed to determine if farming procedures would limit HEV dissemination. Commercial importation of swine is a very common practice and a better surveillance strategy should be developed. Very recently, a genotype 4 was isolated in swine for the first time in Europe ${ }^{4}$. Investigations on the appearance of this genotype are needed. Since swine represent a large reservoir of $\mathrm{HEV}$ in non-endemic region, pigs are probably one of the sources of infection for the sporadic cases of acute hepatitis E. Surveillance of swine, with wild boar and deer reservoirs should be performed until all the routes of human exposure to HEV are identified.

HEV infection can be prevented as well with an efficient immunization program [109]. Since HEV has only one serotype and natural infection leads to protective antibodies [109], HEV is a good candidate for the development of an effective vaccine. A large vaccination campaign in developing countries would reduce large waterborne epidemics with thousands of people concerned. Travellers to endemic regions could also benefit from a vaccine. In industrialized countries, populations at risks such as transplant recipients or people with underlying liver conditions could be a target for vaccination as well. The safety and efficacy of an HEV recombinant protein vaccine was evaluated in a phase 2 , randomized, double-blind, placebo-controlled trial [126]. This vaccine, based on the HEV capsid protein, showed a good efficacy $(88.5 \%$ after one dose and $95.5 \%$ after three doses) in the prevention of hepatitis $E$ in patients [126]. However, with the recent identifications of

\footnotetext{
${ }^{4}$ Van der Poel W., Oral communication, 5th European Meeting on Viral Zoonosis, 26-29 September 2009, St. Raphael, France.
}

genetically distinct strains of HEV in swine, rats and rabbits, it will be important to determine if the experimental vaccines are effective against these emerging and potentially zoonotic strains of HEV.

\section{CONCLUSION}

Although the zoonotic risk of $\mathrm{HEV}$ is now well established, only few cases (two, worldwide) of transmission from animals (deer and wild boar) to humans have been definitively confirmed. Other possible transmission pathways remain to be identified especially in non-endemic countries where the numbers of autochthonous cases are on a steady rise. An important issue of this disease is the evaluation of risk factors associated with $\mathrm{HEV}$ infection and the clinical consequences related to viral exposure. Quantitative risk assessments should be performed to identify and prioritize possible routes of transmission. This approach will contribute to precisely define the strategy of HEV surveillance. The impact of HEV animal reservoirs on human infections must be studied to evaluate whether, and how, zoonotic transmissions should be controlled. Particular attention on HEV genetic variability and recombination in animals must be paid to prevent the potential emergence of more pathogenic strains of HEV.

Acknowledgements. N. Pavio is grateful to ANR, France, grant PNRA HEVZOONEPI, for financial support on HEV research. X.J. Meng's research on $\mathrm{HEV}$ is funded by grants (AI074667 and AI050611) from the U.S. National Institutes of Health (Bethesda, MD, USA).

\section{REFERENCES}

[1] Aggarwal R., Naik S.R., Hepatitis E: intrafamilial transmission versus waterborne spread, J. Hepatol. (1994) 21:718-723.

[2] Aggarwal R., Kini D., Sofat S., Naik S.R., Krawczynski K., Duration of viraemia and faecal viral excretion in acute hepatitis E, Lancet (2000) 356:10811082.

[3] Aggarwal R., Kamili S., Spelbring J., Krawczynski K., Experimental studies on subclinical hepatitis E virus infection in cynomolgus macaques, J. Infect. Dis. (2001) 184:1380-1385. 
[4] Agrawal S., Gupta D., Panda S.K., The $3^{\prime}$ end of hepatitis E virus (HEV) genome binds specifically to the viral RNA-dependent RNA polymerase (RdRp), Virology (2001) 282:87-101.

[5] Andersson M.I., Hughes J., Gordon F.H., Ijaz S., Donati M., Of pigs and pregnancy, Lancet (2008) 372:1192.

[6] Arankalle V.A., Tsarev S.A., Chadha M.S., Alling D.W., Emerson S.U., Banerjee K., Purcell R.H., Agespecific prevalence of antibodies to hepatitis $\mathrm{A}$ and $\mathrm{E}$ viruses in Pune, India, 1982 and 1992, J. Infect. Dis. (1995) 171:447-450.

[7] Arankalle V.A., Joshi M.V., Kulkarni A.M., Gandhe S.S., Chobe L.P., Rautmare S.S., et al., Prevalence of antihepatitis $\mathrm{E}$ virus antibodies in different Indian animal species, J. Viral Hepat. (2001) 8:223-227.

[8] Arankalle V.A., Chobe L.P., Chadha M.S., Type-IV Indian swine HEV infects rhesus monkeys, J. Viral Hepat. (2006) 13:742-745.

[9] Bhatia V., Singhal A., Panda S.K., Acharya S.K., A 20-year single-center experience with acute liver failure during pregnancy: is the prognosis really worse?, Hepatology (2008) 48:1577-1585.

[10] Bigaillon C., Tesse S., Lagathu G., Nicand E., Use of hepatitis E IgG avidity for diagnosis of hepatitis E infection, J. Virol. Methods (2009) 164:127-130.

[11] Bilic I., Jaskulska B., Basic A., Morrow C.J., Hess M., Sequence analysis and comparison of avian hepatitis E viruses from Australia and Europe indicate the existence of different genotypes, J. Gen. Virol. (2009) 90:863-873.

[12] Billam P., Huang F.F., Sun Z.F., Pierson F.W., Duncan R.B., Elvinger F., et al., Systematic pathogenesis and replication of avian hepatitis $\mathrm{E}$ virus in specificpathogen-free adult chickens, J. Virol. (2005) 79:34293437 .

[13] Billam P., Pierson F.W., Li W., LeRoith T., Duncan R.B., Meng X.J., Development and validation of a negative-strand-specific reverse transcription-PCR assay for detection of a chicken strain of hepatitis $E$ virus: identification of nonliver replication sites, J. Clin. Microbiol. (2008) 46:2630-2634.

[14] Blacksell S.D., Myint K.S., Khounsy S., Phruaravanh M., Mammen M.P. Jr, Day N.P., Newton P.N., Prevalence of hepatitis E virus antibodies in pigs: implications for human infections in village-based subsistence pig farming in the Lao PDR, Trans. R. Soc. Trop. Med. Hyg. (2007) 101:305-307.

[15] Bouwknegt M., Lodder-Verschoor F., van der Poel W.H., Rutjes S.A., de Roda Husman A.M., Hepatitis E virus RNA in commercial porcine livers in The Netherlands, J. Food Prot. (2007) 70:2889-2895.

[16] Bouwknegt M., Engel B., Herremans M.M., Widdowson M.A., Worm H.C., Koopmans M.P., et al., Bayesian estimation of hepatitis E virus seroprevalence for populations with different exposure levels to swine in The Netherlands, Epidemiol. Infect. (2008) 136:567-576.
[17] Bouwknegt M., Frankena K., Rutjes S.A., Wellenberg G.J., de Roda Husman A.M., van der Poel W.H., de Jong M.C., Estimation of hepatitis E virus transmission among pigs due to contact-exposure, Vet. Res. (2008) 39:40.

[18] Bouwknegt M., Rutjes S.A., Reusken C.B., Stockhofe-Zurwieden N., Frankena K., de Jong M.C., et al., The course of hepatitis E virus infection in pigs after contact-infection and intravenous inoculation, BMC Vet. Res. (2009) 5:7.

[19] Casas M., Pina S., de Deus N., Peralta B., Martin M., Segales J., Pigs orally inoculated with swine hepatitis E virus are able to infect contact sentinels, Vet. Microbiol. (2009) 138:78-84.

[20] Casas M., Pujols J., Rosell R., de Deus N., Peralta B., Pina S., et al., Retrospective serological study on hepatitis E infection in pigs from 1985 to 1997 in Spain, Vet. Microbiol. (2009) 135:248-252.

[21] Clayson E.T., Innis B.L., Myint K.S., Narupiti S., Vaughn D.W., Giri S., et al., Detection of hepatitis E virus infections among domestic swine in the Kathmandu Valley of Nepal, Am. J. Trop. Med. Hyg. (1995) 53:228-232.

[22] Clemente-Casares P., Pina S., Buti M., Jardi R., Martin M., Bofill-Mas S., Girones R., Hepatitis E virus epidemiology in industrialized countries, Emerg. Infect. Dis. (2003) 9:448-454.

[23] Colson P., Coze C., Gallian P., Henry M., De Micco P., Tamalet C., Transfusion-associated hepatitis E, France, Emerg. Infect. Dis. (2007) 13:648-649.

[24] Colson P., Dhiver C., Gerolami R., Hepatitis E virus as a newly identified cause of acute viral hepatitis during human immunodeficiency virus infection, Clin. Microbiol. Infect. (2008) 14:1176-1180.

[25] Cooper K., Huang F.F., Batista L., Rayo C.D., Bezanilla J.C., Toth T.E., Meng X.J., Identification of genotype 3 hepatitis E virus (HEV) in serum and fecal samples from pigs in Thailand and Mexico, where genotype 1 and $2 \mathrm{HEV}$ strains are prevalent in the respective human populations, J. Clin. Microbiol. (2005) 43:1684-1688.

[26] De Deus N., Casas M., Peralta B., Nofrarias M., Pina S., Martin M., Segales J., Hepatitis E virus infection dynamics and organic distribution in naturally infected pigs in a farrow-to-finish farm, Vet. Microbiol. (2008) 132:19-28.

[27] De Deus N., Peralta B., Pina S., Allepuz A., Mateu E., Vidal D., et al., Epidemiological study of hepatitis E virus infection in European wild boars (Sus scrofa) in Spain, Vet. Microbiol. (2008) 129:163-170.

[28] Drobeniuc J., Favorov M.O., Shapiro C.N., Bell B.P., Mast E.E., Dadu A., et al., Hepatitis E virus antibody prevalence among persons who work with swine, J. Infect. Dis. (2001) 184:1594-1597.

[29] Emerson S.U., Purcell R.H., Hepatitis E virus, Rev. Med. Virol. (2003) 13:145-154. 
[30] Emerson S.U., Anderson D., Arankalle A., Meng X.-J., Purdy M., Schlauder G.G., Tsarev S.A., Hepevirus, in: Fauquet C.M., Mayo M.A., Maniloff J., Desselberger U., Ball L.A. (Eds.), Virus taxonomy, Eighth report of the International Committee on Taxonomy of Viruses, Academic Press, London, United Kingdom, 2004, pp. 851-855.

[31] Engle R.E., Yu C., Emerson S.U., Meng X.J., Purcell R.H., Hepatitis E virus (HEV) capsid antigens derived from viruses of human and swine origin are equally efficient for detecting anti-HEV by enzyme immunoassay, J. Clin. Microbiol. (2002) 40:4576-4580.

[32] Favorov M.O., Kosoy M.Y., Tsarev S.A., Childs J.E., Margolis H.S., Prevalence of antibody to hepatitis E virus among rodents in the United States, J. Infect. Dis. (2000) 181:449-455.

[33] Feagins A.R., Opriessnig T., Guenette D.K., Halbur P.G., Meng X.-J., Detection and characterization of infectious hepatitis $\mathrm{E}$ virus from commercial pig livers sold in local grocery stores in the USA, J. Gen. Virol. (2007) 88:912-917.

[34] Feagins A.R., Opriessnig T., Guenette D.K., Halbur P.G., Meng X.J., Inactivation of infectious hepatitis E virus present in commercial pig livers sold in local grocery stores in the United States, Int. J. Food Microbiol. (2008) 123:32-37.

[35] Feagins A.R., Opriessnig T., Huang Y.W., Halbur P.G., Meng X.J., Cross-species infection of specificpathogen-free pigs by a genotype 4 strain of human hepatitis E virus, J. Med. Virol. (2008) 80:1379-1386.

[36] Fernandez-Barredo S., Galiana C., Garcia A., Vega S., Gomez M.T., Perez-Gracia M.T., Detection of hepatitis $E$ virus shedding in feces of pigs at different stages of production using reverse transcription-polymerase chain reaction, J. Vet. Diagn. Invest. (2006) 18:462-465.

[37] Fogeda M., Avellon A., Cilla C.G., Echevarria J.M., Imported and autochthonous hepatitis $\mathrm{E}$ virus strains in Spain, J. Med. Virol. (2009) 81:1743-1749.

[38] Garkavenko O., Obriadina A., Meng J., Anderson D.A., Benard H.J., Schroeder B.A., et al., Detection and characterisation of swine hepatitis $E$ virus in New Zealand, J. Med. Virol. (2001) 65:525-529.

[39] Graff J., Nguyen H., Yu C., Elkins W.R., St Claire M., Purcell R.H., Emerson S.U., The open reading frame 3 gene of hepatitis E virus contains a cis-reactive element and encodes a protein required for infection of macaques, J. Virol. (2005) 79:6680-6689.

[40] Graff J., Torian U., Nguyen H., Emerson S.U., A bicistronic subgenomic mRNA encodes both the ORF2 and ORF3 proteins of hepatitis E virus, J. Virol. (2006) 80:5919-5926.

[41] Graff J., Zhou Y.H., Torian U., Nguyen H., St Claire M., Yu C., et al., Mutations within potential glycosylation sites in the capsid protein of hepatitis $E$ virus prevent the formation of infectious virus particles, J. Virol. (2008) 82:1185-1194.
[42] Guimaraes F.R., Saddi T.M., Vitral C.L., Pinto M.A., Gaspar A.M.C., Souto F.J.D., Hepatitis E virus antibodies in swine herds of Mato Grosso State, Central Brazil, Braz. J. Microbiol. (2005) 36:223-226.

[43] Guo H., Zhou E.M., Sun Z.F., Meng X.J., Egg whites from eggs of chickens infected experimentally with avian hepatitis E virus contain infectious virus, but evidence of complete vertical transmission is lacking, J. Gen. Virol. (2007) 88:1532-1537.

[44] Gyarmati P., Mohammed N., Norder H., Blomberg J., Belak S., Widen F., Universal detection of hepatitis E virus by two real-time PCR assays: TaqMan and PrimerProbe Energy Transfer, J. Virol. Methods (2007) 146:226235

[45] Halbur P.G., Kasorndorkbua C., Gilbert C., Guenette D., Potters M.B., Purcell R.H., et al., Comparative pathogenesis of infection of pigs with hepatitis $\mathrm{E}$ viruses recovered from a pig and a human, J. Clin. Microbiol. (2001) 39:918-923.

[46] Haqshenas G., Shivaprasad H.L., Woolcock P.R., Read D.H., Meng X.J., Genetic identification and characterization of a novel virus related to human hepatitis $\mathrm{E}$ virus from chickens with hepatitis-splenomegaly syndrome in the United States, J. Gen. Virol. (2001) 82:24492462.

[47] Hirano M., Ding X., Li T.C., Takeda N., Kawabata H., Koizumi N., et al., Evidence for widespread infection of hepatitis E virus among wild rats in Japan, Hepatol. Res. (2003) 27:1-5.

[48] Huang C.C., Nguyen D., Fernandez J., Yun K.Y., Fry K.E., Bradley D.W., et al., Molecular cloning and sequencing of the Mexico isolate of hepatitis $E$ virus (HEV), Virology (1992) 191:550-558.

[49] Huang F.F., Haqshenas G., Guenette D.K., Halbur P.G., Schommer S.K., Pierson F.W., et al., Detection by reverse transcription-PCR and genetic characterization of field isolates of swine hepatitis E virus from pigs in different geographic regions of the United States, J. Clin. Microbiol. (2002) 40:1326-1332.

[50] Huang F.F., Haqshenas G., Shivaprasad H.L., Guenette D.K., Woolcock P.R., Larsen C.T., et al., Heterogeneity and seroprevalence of a newly identified avian hepatitis E virus from chickens in the United States, J. Clin. Microbiol. (2002) 40:4197-4202.

[51] Huang F.F., Sun Z.F., Emerson S.U., Purcell R.H., Shivaprasad H.L., Pierson F.W., et al., Determination and analysis of the complete genomic sequence of avian hepatitis $\mathrm{E}$ virus (avian HEV) and attempts to infect rhesus monkeys with avian HEV, J. Gen. Virol. (2004) 85:1609-1618.

[52] Huang Y.W., Opriessnig T., Halbur P.G., Meng X.J., Initiation at the third in-frame AUG codon of open reading frame 3 of the hepatitis $\mathrm{E}$ virus is essential for viral infectivity in vivo, J. Virol. (2007) 81:3018-3026.

[53] Hussaini S.H., Skidmore S.J., Richardson P., Sherratt L.M., Cooper B.T., O'Grady J.G., Severe hepatitis 
E infection during pregnancy, J. Viral Hepat. (1997) 4: 51-54.

[54] Jimenez de Oya N., Galindo I., Girones O., Duizer E., Escribano J.M., Saiz J.C., Serological immunoassay for detection of hepatitis $\mathrm{E}$ virus on the basis of genotype 3 open reading frame 2 recombinant proteins produced in Trichoplusia ni larvae, J. Clin. Microbiol. (2009) 47:3276-3282.

[55] Johne R., Plenge-Bonig A., Hess M., Ulrich R.G., Reetz J., Schielke A., Detection of a novel hepatitis E-like virus in faeces of wild rats using a nested broad-spectrum RT-PCR, J. Gen. Virol. (2009) 91:750-758.

[56] Jothikumar N., Cromeans T.L., Robertson B.H., Meng X.J., Hill V.R., A broadly reactive one-step realtime RT-PCR assay for rapid and sensitive detection of hepatitis E virus, J. Virol. Methods (2006) 131:65-71.

[57] Jung K., Kang B., Song D.S., Chae C., Prevalence and genotyping of hepatitis $\mathrm{E}$ virus in swine population in Korea between 1995 and 2004: a retrospective study, Vet. J. (2007) 173:683-687.

[58] Kaba M., Davoust B., Marie J.L., Colson P., Detection of hepatitis E virus in wild boar (Sus scrofa) livers, Vet. J. (2009) doi:10.1016/j.tvj1.2009.08.008.

[59] Kabrane-Lazizi Y., Fine J.B., Elm J., Glass G.E., Higa H., Diwan A., et al., Evidence for widespread infection of wild rats with hepatitis E virus in the United States, Am. J. Trop. Med. Hyg. (1999) 61:331-335.

[60] Kabrane-Lazizi Y., Meng X.J., Purcell R.H., Emerson S.U., Evidence that the genomic RNA of hepatitis E virus is capped, J. Virol. (1999) 73:8848-8850.

[61] Kaci S., Nockler K., Johne R., Detection of hepatitis E virus in archived German wild boar serum samples, Vet. Microbiol. (2008) 128:380-385.

[62] Kamar N., Mansuy J.M., Cointault O., Selves J., Abravanel F., Danjoux M., et al., Hepatitis E virus-related cirrhosis in kidney- and kidney-pancreas-transplant recipients, Am. J. Transplant. (2008) 8:1744-1748.

[63] Kamar N., Selves J., Mansuy J.M., Ouezzani L., Peron J.M., Guitard J., et al., Hepatitis E virus and chronic hepatitis in organ-transplant recipients, N. Engl. J. Med. (2008) 358:811-817.

[64] Kasorndorkbua C., Thacker B.J., Halbur P.G., Guenette D.K., Buitenwerf R.M., Royer R.L., Meng X.J., Experimental infection of pregnant gilts with swine hepatitis E virus, Can. J. Vet. Res. (2003) 67:303-306.

[65] Kasorndorkbua C., Guenette D.K., Huang F.F., Thomas P.J., Meng X.J., Halbur P.G., Routes of transmission of swine hepatitis $\mathrm{E}$ virus in pigs, J. Clin. Microbiol. (2004) 42:5047-5052.

[66] Kasorndorkbua C., Opriessnig T., Huang F.F., Guenette D.K., Thomas P.J., Meng X.J., Halbur P.G., Infectious swine hepatitis $\mathrm{E}$ virus is present in pig manure storage facilities on United States farms, but evidence of water contamination is lacking, Appl. Environ. Microbiol. (2005) 71:7831-7837.
[67] Khuroo M.S., Kamili S., Jameel S., Vertical transmission of hepatitis E virus, Lancet (1995) 345:10251026.

[68] Koonin E.V., Gorbalenya A.E., Purdy M.A., Rozanov M.N., Reyes G.R., Bradley D.W., Computerassisted assignment of functional domains in the nonstructural polyprotein of hepatitis E virus: delineation of an additional group of positive-strand RNA plant and animal viruses, Proc. Natl. Acad. Sci. USA (1992) 89:8259-8263.

[69] Krawczynski K., Aggarwal R., Kamili S., Hepatitis E, Infect. Dis. Clin. North Am. (2000) 14:669-687.

[70] Kulkarni M.A., Arankalle V.A., The detection and characterization of hepatitis $\mathrm{E}$ virus in pig livers from retail markets of India, J. Med. Virol. (2008) 80:13871390.

[71] Le Coutre P., Meisel H., Hofmann J., Rocken C., Vuong G.L., Neuburger S., et al., Reactivation of hepatitis $E$ infection in a patient with acute lymphoblastic leukaemia after allogeneic stem cell transplantation, Gut (2009) 58:699-702.

[72] Leblanc D., Ward P., Gagne M.J., Poitras E., Muller P., Trottier Y.L., et al., Presence of hepatitis E virus in a naturally infected swine herd from nursery to slaughter, Int. J. Food Microbiol. (2007) 117:160-166.

[73] Lee Y.H., Ha Y., Ahn K.K., Chae C., Localisation of swine hepatitis $\mathrm{E}$ virus in experimentally infected pigs, Vet. J. (2009) 179:417-421.

[74] Legrand-Abravanel F., Thevenet I., Mansuy J.M., Saune K., Vischi F., Peron J.M., et al., Good performance of immunoglobulin $\mathrm{M}$ assays in diagnosing genotype 3 hepatitis $\mathrm{E}$ virus infections, Clin. Vaccine Immunol. (2009) 16:772-774.

[75] Li T.C., Yamakawa Y., Suzuki K., Tatsumi M., Razak M.A., Uchida T., et al., Expression and selfassembly of empty virus-like particles of hepatitis E virus, J. Virol. (1997) 71:7207-7213.

[76] Li T.C., Chijiwa K., Sera N., Ishibashi T., Etoh Y., Shinohara Y., et al., Hepatitis E virus transmission from wild boar meat, Emerg. Infect. Dis. (2005) 11:1958-1960.

[77] Li T.C., Saito M., Ogura G., Ishibashi O., Miyamura T., Takeda N., Serologic evidence for hepatitis E virus infection in mongoose, Am. J. Trop. Med. Hyg. (2006) 74:932-936.

[78] Lu L., Li C., Hagedorn C.H., Phylogenetic analysis of global hepatitis E virus sequences: genetic diversity, subtypes and zoonosis, Rev. Med. Virol. (2006) 16:5-36.

[79] Madejon A., Vispo E., Bottecchia M., SanchezCarrillo M., Garcia-Samaniego J., Soriano V., Lack of hepatitis $\mathrm{E}$ virus infection in HIV patients with advanced immunodeficiency or idiopathic liver enzyme elevations, J. Viral Hepat. (2009) 16:895-896.

[80] Mansuy J.M., Abravanel F., Miedouge M., Mengelle C., Merviel C., Dubois M., et al., Acute 
hepatitis E in south-west France over a 5-year period, J. Clin. Virol. (2009) 44:74-77.

[81] Martelli F., Caprioli A., Zengarini M., Marata A., Fiegna C., Di Bartolo I., et al., Detection of hepatitis E virus (HEV) in a demographic managed wild boar (Sus scrofa scrofa) population in Italy, Vet. Microbiol. (2008) 126:74-81.

[82] Martin M., Segales J., Huang F.F., Guenette D.K., Mateu E., de Deus N., Meng X.J., Association of hepatitis $\mathrm{E}$ virus (HEV) and postweaning multisystemic wasting syndrome (PMWS) with lesions of hepatitis in pigs, Vet. Microbiol. (2007) 122:16-24.

[83] Masuda J., Yano K., Tamada Y., Takii Y., Ito M., Omagari K., Kohno S., Acute hepatitis E of a man who consumed wild boar meat prior to the onset of illness in Nagasaki, Japan, Hepatol. Res. (2005) 31:178-183.

[84] Matsubayashi K., Kang J.H., Sakata H., Takahashi K., Shindo M., Kato M., et al., A case of transfusiontransmitted hepatitis E caused by blood from a donor infected with hepatitis E virus via zoonotic food-borne route, Transfusion (2008) 48: 1368-1375.

[85] Matsuda H., Okada K., Takahashi K., Mishiro S., Severe hepatitis E virus infection after ingestion of uncooked liver from a wild boar, J. Infect. Dis. (2003) 188:944

[86] Matsuura Y., Suzuki M., Yoshimatsu K., Arikawa J., Takashima I., Yokoyama M., et al., Prevalence of antibody to hepatitis E virus among wild sika deer, Cervus nippon, in Japan, Arch. Virol. (2007) 152:13751381.

[87] McCaustland K.A., Krawczynski K., Ebert J.W., Balayan M.S., Andjaparidze A.G., Spelbring J.E., et al., Hepatitis $\mathrm{E}$ virus infection in chimpanzees: a retrospective analysis, Arch. Virol. (2000) 145: 19091918.

[88] McCreary C., Martelli F., Grierson S., Ostanello F., Nevel A., Banks M., Excretion of hepatitis E virus by pigs of different ages and its presence in slurry stores in the United Kingdom, Vet. Rec. (2008) 163:261-265.

[89] Meng X.J., Purcell R.H., Halbur P.G., Lehman J.R., Webb D.M., Tsareva T.S., et al., A novel virus in swine is closely related to the human hepatitis E virus, Proc. Natl. Acad. Sci. USA (1997) 94:9860-9865.

[90] Meng X.J., Halbur P.G., Haynes J.S., Tsareva T.S., Bruna J.D., Royer R.L., et al., Experimental infection of pigs with the newly identified swine hepatitis E virus (swine HEV), but not with human strains of HEV, Arch. Virol. (1998) 143:1405-1415.

[91] Meng X.J., Halbur P.G., Shapiro M.S., Govindarajan S., Bruna J.D., Mushahwar I.K., et al., Genetic and experimental evidence for cross-species infection by swine hepatitis E virus, J. Virol. (1998) 72:9714-9721.

[92] Meng X.J., Dea S., Engle R.E., Friendship R., Lyoo Y.S., Sirinarumitr T., et al., Prevalence of antibodies to the hepatitis $\mathrm{E}$ virus in pigs from countries where hepatitis E is common or is rare in the human population, J. Med Virol. (1999) 59:297-302.

[93] Meng X.J., Wiseman B., Elvinger F., Guenette D.K., Toth T.E., Engle R.E., et al., Prevalence of antibodies to hepatitis $\mathrm{E}$ virus in veterinarians working with swine and in normal blood donors in the United States and other countries, J. Clin. Microbiol. (2002) 40:117-122.

[94] Meng X.J., Swine hepatitis E virus: cross-species infection and risk in xenotransplantation, Curr. Top. Microbiol. Immunol. (2003) 278:185-216.

[95] Meng X.J., Hepatitis E virus: animal reservoirs and zoonotic risk, Vet. Microbiol. (2009) 140:256-265.

[96] Michitaka K., Takahashi K., Furukawa S., Inoue G., Hiasa Y., Horiike N., et al., Prevalence of hepatitis E virus among wild boar in the Ehime area of western Japan, Hepatol. Res. (2007) 37:214-220.

[97] Munne M.S., Vladimirsky S., Otegui L., Castro R., Brajterman L., Soto S., et al., Identification of the first strain of swine hepatitis E virus in South America and prevalence of anti-HEV antibodies in swine in Argentina, J. Med. Virol. (2006) 78:1579-1583.

[98] Nakai I., Kato K., Miyazaki A., Yoshii M., Li T.C., Takeda N., et al., Different fecal shedding patterns of two common strains of hepatitis E virus at three Japanese swine farms, Am. J. Trop. Med. Hyg. (2006) 75:11711177.

[99] Nakamura M., Takahashi K., Taira K., Taira M., Ohno A., Sakugawa H., et al., Hepatitis E virus infection in wild mongooses of Okinawa, Japan: demonstration of anti-HEV antibodies and a full-genome nucleotide sequence, Hepatol. Res. (2006) 34:137-140.

[100] Navaneethan U., Al Mohajer M., Shata M.T., Hepatitis E and pregnancy: understanding the pathogenesis, Liver Int. (2008) 28:1190-1199.

[101] Okamoto H., Genetic variability and evolution of hepatitis E virus, Virus Res. (2007) 127:216-228.

[102] Olsen B., Axelsson-Olsson D., Thelin A., Weiland O., Unexpected high prevalence of IgG-antibodies to hepatitis $\mathrm{E}$ virus in Swedish pig farmers and controls, Scand. J. Infect. Dis. (2006) 38:55-58.

[103] Panda S.K., Ansari I.H., Durgapal H., Agrawal S., Jameel S., The in vitro-synthesized RNA from a cDNA clone of hepatitis E virus is infectious, J. Virol. (2000) 74:2430 2437.

[104] Peralta B., Biarnes M., Ordonez G., Porta R., Martin M., Mateu E., et al., Evidence of widespread infection of avian hepatitis E virus (avian HEV) in chickens from Spain, Vet. Microbiol. (2009) 137:31-36.

[105] Peralta B., Casas M., de Deus N., Martin M., Ortuno A., Perez-Martin E., et al., Anti-HEV antibodies in domestic animal species and rodents from Spain using a genotype 3-based ELISA, Vet. Microbiol. (2009) 137:6673.

[106] Peralta B., Mateu E., Casas M., de Deus N., Martin M., Pina S., Genetic characterization of the complete 
coding regions of genotype 3 hepatitis E virus isolated from Spanish swine herds, Virus Res. (2009) 139:111116.

[107] Peron J.M., Bureau C., Poirson H., Mansuy J.M., Alric L., Selves J., et al., Fulminant liver failure from acute autochthonous hepatitis E in France: description of seven patients with acute hepatitis $\mathrm{E}$ and encephalopathy, J. Viral Hepat. (2007) 14:298-303.

[108] Purcell R.H., Emerson S.U., Animal models of hepatitis A and E, ILAR J. (2001) 42:161-177.

[109] Purcell R.H., Emerson S.U., Hepatitis E: an emerging awareness of an old disease, J. Hepatol. (2008) 48:494-503.

[110] Rehman S., Kapur N., Durgapal H., Panda S.K., Subcellular localization of hepatitis E virus (HEV) replicase, Virology (2008) 370:77-92.

[111] Renou C., Cadranel J.F., Bourlière M., Halfon P., Ouzan D., Rifflet H., et al., Possible zoonotic transmission of hepatitis E from a pet pig to its owner, Emerg. Infect. Dis. (2007) 13:1094-1096.

[112] Renou C., Pariente A., Nicand E., Pavio N., Pathogenesis of hepatitis $\mathrm{E}$ in pregnancy, Liver Int. (2008) 28:1465; author reply 1466 .

[113] Renou C., Lafeuillade A., Pavio N., Nicand E., Response to Madejon et al., Are HIV-infected patients at risk of HEV infection?, J. Viral Hepat. (2010) (in press).

[114] Renou C., Nicand E., Pariente A., Cadranel J.F., Pavio N., How to detect and diagnose an autochthonous hepatitis E?, Gastroenterol. Clin. Biol. (2009) 33:F27-F35 (in French).

[115] Reuter G., Fodor D., Forgach P., Katai A., Szucs G., Characterization and zoonotic potential of endemic hepatitis E virus (HEV) strains in humans and animals in Hungary, J. Clin. Virol. (2009) 44:277-281.

[116] Reyes G.R., Purdy M.A., Kim J.P., Luk K.C., Young L.M., Fry K.E., Bradley D.W., Isolation of a cDNA from the virus responsible for enterically transmitted non-A, non-B hepatitis, Science (1990) 247:13351339 .

[117] Ropp S.L., Tam A.W., Beames B., Purdy M., Frey T.K., Expression of the hepatitis E virus ORF1, Arch. Virol. (2000) 145:1321-1337.

[118] Rose N., Boutrouille A., Fablet C., Madec F., Eloit M., Pavio N., The use of Bayesian methods for evaluating the performance of a virus-like particles-based ELISA for serology of hepatitis E virus infection in swine, J. Virol. Methods (2010) 163:329-335.

[119] Rutjes S.A., Lodder W.J., Bouwknegt M., de Roda Husman A.M., Increased hepatitis E virus prevalence on Dutch pig farms from 33 to $55 \%$ by using appropriate internal quality controls for RT-PCR, J. Virol. Methods (2007) 143:112-116.

[120] Rutjes S.A., Lodder W.J., Lodder-Verschoor F., van den Berg H.H., Vennema H., Duizer E., et al., Sources of hepatitis E virus genotype 3 in The Netherlands, Emerg. Infect. Dis. (2009) 15:381-387.

[121] Saad M.D., Hussein H.A., Bashandy M.M., Kamel H.H., Earhart K.C., Fryauff D.J., et al., Hepatitis E virus infection in work horses in Egypt, Infect. Genet. Evol. (2007) 7:368-373.

[122] Schielke A., Sachs K., Lierz M., Appel B., Jansen A., Johne R., Detection of hepatitis E virus in wild boars of rural and urban regions in Germany and whole genome characterization of an endemic strain, Virol. J. (2009) 6:58.

[123] Schlauder G.G., Dawson G.J., Erker J.C., Kwo P.Y., Knigge M.F., Smalley D.L., et al., The sequence and phylogenetic analysis of a novel hepatitis E virus isolated from a patient with acute hepatitis reported in the United States, J. Gen. Virol. (1998) 79:447-456.

[124] Sehgal D., Thomas S., Chakraborty M., Jameel S., Expression and processing of the hepatitis E virus ORF1 nonstructural polyprotein, Virol. J. (2006) 3:38.

[125] Seminati C., Mateu E., Peralta B., de Deus N., Martin M., Distribution of hepatitis E virus infection and its prevalence in pigs on commercial farms in Spain, Vet. J. (2008) 175:130-132.

[126] Shrestha M.P., Scott R.M., Joshi D.M., Mammen M.P. Jr, Thapa G.B., Thapa N., et al., Safety and efficacy of a recombinant hepatitis E vaccine, N. Engl. J. Med. (2007) 356:895-903.

[127] Sonoda H., Abe M., Sugimoto T., Sato Y., Bando M., Fukui E., et al., Prevalence of hepatitis E virus (HEV) Infection in wild boars and deer and genetic identification of a genotype $3 \mathrm{HEV}$ from a boar in Japan, J. Clin. Microbiol. (2004) 42:5371-5374.

[128] Srivastava R., Aggarwal R., Jameel S., Puri P., Gupta V.K., Ramesh V.S., et al., Cellular immune responses in acute hepatitis $\mathrm{E}$ virus infection to the viral open reading frame 2 protein, Viral Immunol. (2007) 20:56-65.

[129] Stoszek S.K., Engle R.E., Abdel-Hamid M., Mikhail N., Abdel-Aziz F., Medhat A., et al., Hepatitis E antibody seroconversion without disease in highly endemic rural Egyptian communities, Trans. R. Soc. Trop. Med. Hyg. (2006) 100:89-94.

[130] Sun Z.F., Larsen C.T., Huang F.F., Billam P., Pierson F.W., Toth T.E., Meng X.J., Generation and infectivity titration of an infectious stock of avian hepatitis E virus (HEV) in chickens and cross-species infection of turkeys with avian HEV, J. Clin. Microbiol. (2004) 42:2658-2662.

[131] Surjit M., Jameel S., Lal S.K., The ORF2 protein of hepatitis $\mathrm{E}$ virus binds the $5^{\prime}$ region of viral RNA, J. Virol. (2004) 78:320-328.

[132] Surjit M., Jameel S., Lal S.K., Cytoplasmic localization of the ORF2 protein of hepatitis E virus is dependent on its ability to undergo retrotranslocation from the endoplasmic reticulum, J. Virol. (2007) 81:33393345 . 
[133] Takahashi K., Kitajima N., Abe N., Mishiro S., Complete or near-complete nucleotide sequences of hepatitis $\mathrm{E}$ virus genome recovered from a wild boar, a deer, and four patients who ate the deer, Virology (2004) 330:501-505.

[134] Takahashi M., Nishizawa T., Tanaka T., TsatsraltOd B., Inoue J., Okamoto H., Correlation between positivity for immunoglobulin A antibodies and viraemia of swine hepatitis $\mathrm{E}$ virus observed among farm pigs in Japan, J. Gen. Virol. (2005) 86: 1807-1813.

[135] Tam A.W., Smith M.M., Guerra M.E., Huang C.C., Bradley D.W., Fry K.E., Reyes G.R., Hepatitis E virus (HEV): molecular cloning and sequencing of the fulllength viral genome, Virology (1991) 185:120-131.

[136] Tam A.W., White R., Reed E., Short M., Zhang Y., Fuerst T.R., Lanford R.E., In vitro propagation and production of hepatitis $\mathrm{E}$ virus from in vivo-infected primary macaque hepatocytes, Virology (1996) 215:1-9.

[137] Tamada Y., Yano K., Yatsuhashi H., Inoue O., Mawatari F., Ishibashi H., Consumption of wild boar linked to cases of hepatitis E, J. Hepatol. (2004) 40:869870 .

[138] Tei S., Kitajima N., Takahashi K., Mishiro S., Zoonotic transmission of hepatitis $\mathrm{E}$ virus from deer to human beings, Lancet (2003) 362:371-373.

[139] Thoden J., Venhoff N., Miehle N., Klar M., Huzly D., Panther E., et al., Hepatitis E and jaundice in an HIVpositive pregnant woman, AIDS (2008) 22:909-910.

[140] Tien N.T., Clayson H.T., Khiem H.B., Sac P.K., Corwin A.L., Myint K.S., Vaughn D.W., Detection of immunoglobulin $\mathrm{G}$ to the hepatitis $\mathrm{E}$ virus among several animal species in Vietnam, Am. J. Trop. Med. Hyg. (1997) 57:211

[141] Tomiyama D., Inoue E., Osawa Y., Okazaki K., Serological evidence of infection with hepatitis E virus among wild Yezo-deer, Cervus nippon yesoensis, in Hokkaido, Japan, J. Viral Hepat. (2009) 16:524-528.

[142] Tyagi S., Korkaya H., Zafrullah M., Jameel S., Lal S.K., The phosphorylated form of the ORF3 protein of hepatitis E virus interacts with its non-glycosylated form of the major capsid protein, ORF2, J. Biol. Chem. (2002) 277:22759-22767.

[143] Ward P., Poitras E., Leblanc D., Letellier A., Brassard J., Plante D., Houde A., Comparative analysis of different TaqMan real-time RT-PCR assays for the detection of swine hepatitis $\mathrm{E}$ virus and integration of Feline calicivirus as internal control, J. Appl. Microbiol. (2009) 106:1360-1369.

[144] Wichmann O., Schimanski S., Koch J., Kohler M., Rothe C., Plentz A., et al., Phylogenetic and case-control study on hepatitis E virus infection in Germany, J. Infect. Dis. (2008) 198:1732-1741.

[145] Williams T.P., Kasorndorkbua C., Halbur P.G., Haqshenas G., Guenette D.K., Toth T.E., Meng X.J., Evidence of extrahepatic sites of replication of the hepatitis E virus in a swine model, J. Clin. Microbiol. (2001) 39:3040-3046.

[146] Withers M.R., Correa M.T., Morrow M., Stebbins M.E., Seriwatana J., Webster W.D., et al., Antibody levels to hepatitis E virus in North Carolina swine workers, nonswine workers, swine, and murids, Am. J. Trop. Med. Hyg. (2002) 66:384-388.

[147] Xing L., Kato K., Li T., Takeda N., Miyamura T., Hammar L., Cheng R.H., Recombinant hepatitis E capsid protein self-assembles into a dual-domain $\mathrm{T}=1$ particle presenting native virus epitopes, Virology (1999) 265:3545.

[148] Yamada K., Takahashi M., Hoshino Y., Takahashi H., Ichiyama K., Nagashima S., et al., ORF3 protein of hepatitis $\mathrm{E}$ virus is essential for virion release from infected cells, J. Gen. Virol. (2009) 90:1880-1891.

[149] Yazaki Y., Mizuo H., Takahashi M., Nishizawa T., Sasaki N., Gotanda Y., Okamoto H., Sporadic acute or fulminant hepatitis $\mathrm{E}$ in Hokkaido, Japan, may be foodborne, as suggested by the presence of hepatitis $\mathrm{E}$ virus in pig liver as food, J. Gen. Virol. (2003) 84:2351-2357.

[150] Zafrullah M., Ozdener M.H., Kumar R., Panda S.K., Jameel S., Mutational analysis of glycosylation, membrane translocation, and cell surface expression of the hepatitis E virus ORF2 protein, J. Virol. (1999) 73:40744082 .

[151] Zhang M., Emerson S.U., Nguyen H., Engle R., Govindarajan S., Blackwelder W.C., et al., Recombinant vaccine against hepatitis $\mathrm{E}$ : duration of protective immunity in rhesus macaques, Vaccine (2002) 20:3285-3291.

[152] Zhang W., Shen Q., Mou J., Gong G., Yang Z., Cui L., et al., Hepatitis E virus infection among domestic animals in eastern China, Zoonoses Public Health (2008) $55: 291-298$

[153] Zhao C., Li Z., Yan B., Harrison T.J., Guo X., Zhang F., et al., Comparison of real-time fluorescent RTPCR and conventional RT-PCR for the detection of hepatitis E virus genotypes prevalent in China, J. Med. Virol. (2007) 79:1966-1973.

[154] Zhao C., Ma Z., Harrison T.J., Feng R., Zhang C., Qiao Z., et al., A novel genotype of hepatitis E virus prevalent among farmed rabbits in China, J. Med. Virol. (2009) 81:1371-1379. 